\title{
Chlorococcum humicola (Nageli) Rabenhorst as a Renewable Source of Bioproducts and Biofuel
}

\author{
Santhoshkumar K. ${ }^{1}$, Prasanthkumar S. ${ }^{1} \&$ J. G. Ray ${ }^{1}$ \\ ${ }^{1}$ Laboratory of Ecology \& Ecotechnology, School of Biosciences, Mahatma Gandhi University, Kottayam, \\ Kerala, India \\ Correspondence: J. G. Ray, Laboratory of Ecology \& Ecotechnology, School of Biosciences, Mahatma Gandhi \\ University, Kottayam, Kerala, India. E-mail: jgray@mgu.ac.in
}

Received: December 1, 2015

Accepted: January 3, 2016 Online Published: February 29, 2016

doi:10.5539/jps.v5n1p48

URL: http://dx.doi.org/10.5539/jps.v5n1p48

\begin{abstract}
Among the diverse new generation biomass yielding species, green algae are the most promising organisms. Compared to biomass production of other organisms, production of algae is less laborious, quite fast, and more economical. Moreover, eutrophicated waters get naturally purified in the cultivation process of algae. Algal biomass from monoculture of specific species, which are rich in carbohydrates, proteins and lipids, is considered a good source of diverse bio-products and feed-stock for food, feeds and bio-fuels. Quantity and quality of algal biomass for specific products depend on the species and strains as well as environmental conditions of cultivation. In this connection, biomass productivity and oil-yield of a local strain of Chlorococcum humicola (Nageli) Rabenhorst was assessed in Bold's Basal Medium. Long-term storage capacity of the alga was tried by entrapping the algal cells in sodium alginate beads, which showed viability up to 14 months. Estimation of total carbohydrate, protein, lipid and chemical characterization of oil as well as the feasibility of its conversion to biodiesel revealed the industrial potential of this local strain as a source of food and biofuel. Fatty acid profiling of the extracted oil showed that $70 \%$ are mono-saturated and $12.2 \%$ are nutritionally important polyunsaturated fatty acids. The oil could be effectively trans-esterified to methyl esters and the conversion was confirmed by FTIR spectroscopy. Further standardization of the mass production of the alga in natural environmental conditions for biomass and oil is progressing to optimize its value as globally competent food, nutraceutical and biofuel resource.
\end{abstract}

Keywords: Chlorococcum humicola, algal biomass, algal biodiesel, algal bioproducts, synthetic seed

\section{Introduction}

Green algae are significant new biomass resource for the production of natural bioactive compounds and renewable energy. They have unique nutritional quality (Becker, 2007) that can add value to conventional food preparations for humans and animals. Because of the high protein content, biomass from many species of microalgae is generally considered as the potential source of proteins (Spolaore, Joannis-Cassan, Duran, \& Isambert, 2006) for the future. In addition to proteins, green algae are good source of carbohydrates and lipids for food and fuels. Among the known commercially and industrially amenable green resources, algae can provide the highest and cheapest biomass per unit light and area. Simultaneously they can remediate nutrient load or degrade other toxic pollutants in water (Chiu et al., 2015) and reducing atmospheric $\mathrm{CO}_{2}$ level through carbon fixation process (Morais \& Costa, 2007). Moreover, several pharmaceutical products are derived from algal biomass (Yamaguchi, 1997), especially from that of Chlorophytes.

Biopharmaceutical industries are in search of low cost biomaterials for production of therapeutics in a sustainable manner (Johnson, 2008). Chlorococcum humicola (Nageli) Rabenhorst (Figure 1) is a freshwater unicellular green alga coming under the class Chlorophyta. Even though C. humicola is proved to be a rich source of structurally novel and biologically active metabolites (Bhagavathy, Sumathi \& Jancy Sherene Bell, 2011), biomass-productivity of its specific strains are not well known.

Long-term storage of algal stock in sodium alginate beads in pure culture form is useful for stock culture management (Gaudin, Lebeau, \& Robert , 2006) as well as long term storage of the algal seeds (Faafeng, Donk, \& Källqvist, 1994) for biomass production and production of secondary metabolites (Moreno-Garrido, 2008). Immobilized algae can also be used in wastewater treatment (Travieso et al., 1996) and removal of heavy metals 
from waste water (Becker, 1994; Murugesan, Maheswari, \& Bagirath, 2008). However, specific methods to develop a seed material of this alga for convenient mass-cultivation remain quite unexplored.

Protein content of green algae varies depending upon the species and strains (Fleurence, 1999; Gatenby et al., 2003). In addition to proteins, carbohydrates present in algae are also variable that have important value as food and fuels. Algal carbohydrates are easily digestible compounds that have high demand in the preparation of conventional foods, pharmaceutical and nutraceutical compounds (Becker, 2007). Moreover, the residual biomass rich in carbohydrates after the extraction of lipids or proteins is used for the production of ethanol (Gao, Shimamura, Ishida, \& Takahashi, 2012). Some of the algal lipids such as omega-3 fatty acid and DHA are nutritionally valuable (Spolaore, Joannis-Cassan, Duran, \& Isambert, 2006). Polyunsaturated fatty acids, especially omega-3 and omega- 6 in algal oils are used as medicines for health of heart and brain (Ignarro, Balestrieri, \& Napoli, 2007). Essential fatty acids present in algae are used as dietary supplements in many pharmaceutical products (Benatti, Peluso, Nicolai, \& Calvani, 2004). Algal biomass rich in oils is also used as a natural source of bio-fuels, which is highly cost effective, environmental-friendly and renewable source of liquid fuel (Scott \& Bryner, 2006). However, magnitude of oil and biomass production of an alga depends on the cultural conditions and biomass productivity (Olofsson et al., 2012). Naturally, chemical characterization of the bio-oil as well as the general biomass of hitherto unexplored species and local strains of green algae becomes quite meaningful. Such kinds of data are universally significant to assess the industrial potential of new species or strains of algae.

Assessment of biomass productivity, total proteins, carbohydrates and lipid content as well as lipid characterization of a local strain of $C$. humicola was the major objective of the current investigation. Since trials of long-term storage are essential to ensure continuous industrial production of algae, synthetic seed preparation and its viability in the 'seed form' became another objective. Overall, the present investigation point to the significance of a local strain of C. humicola as a potential feed-stock for food and fuel. Synthetic seeds of this alga could be preserved for more than a year.

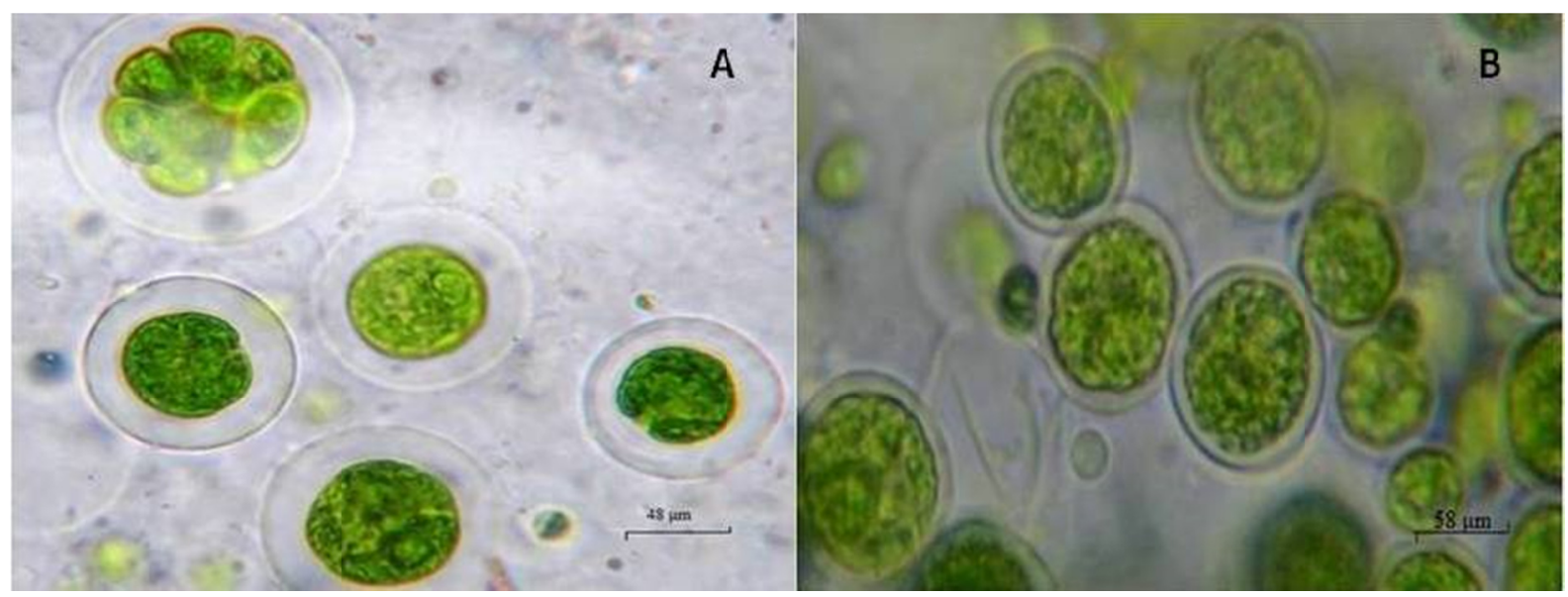

Figure 1. Chlorococcum humicola showing solitary cells (A) and colonial cells (B)

\section{Materials and methods}

\subsection{In vitro Culture of Algae}

C. humicola is unicellular, non-motile, spherical cells having smooth cell walls. Cells are seen in colonies or solitary and are varied in sizes $(48 \mu \mathrm{m}-58 \mu \mathrm{m})$ having a 'hollow sphere like chloroplast', completely filling each cell, with a lateral notch and a single pyrenoid (Phillipose, 1967). In the current investigation, viable cells of a local strain of $C$. humicola were isolated from a fresh water temple pond $\left(9^{\circ} 45^{\prime} 02.9^{\prime \prime} \mathrm{N} 76^{\circ} 23^{\prime} 45.6^{\prime \prime} \mathrm{E}\right)$ of Kottayam District of Kerala, India. Pure culture of the strain in BBM is maintained in the algal culture facility centre in the Ecotechnology Laboratory, School of Biosciences, Mahatma Gandhi University.

Temperature and $\mathrm{pH}$ of the collected water samples were measured. $100 \mathrm{mg}$ of fresh biomass after centrifugation of the pure culture was inoculated and cultured in one litre flasks using Bold's Basal Medium (BBM) (Andersen, 2005 ) in triplicate (Figure 2). All the culture vessels were incubated under controlled conditions of light (8000 Lux), temperature $\left(24 \pm 2^{\circ} \mathrm{C}\right)$ and $\mathrm{pH}(7.30)$. Productivity was measured on completion of 30 days of growth. On 
completion of the incubation period, biomass was collected by centrifugation and the solid biomass was further air dried. Percentage increase of biomass per day per litre was calculated as productivity of algae as per the formula:

$$
\% \text { of Biomass productivity of algae } / \mathrm{L} / \text { day }=\frac{\text { Final dry weight }}{\text { Initial dry weight } \mathrm{x} \text { total no. of culturing days } \mathrm{x} \text { Vol. }} \times 100 \%
$$

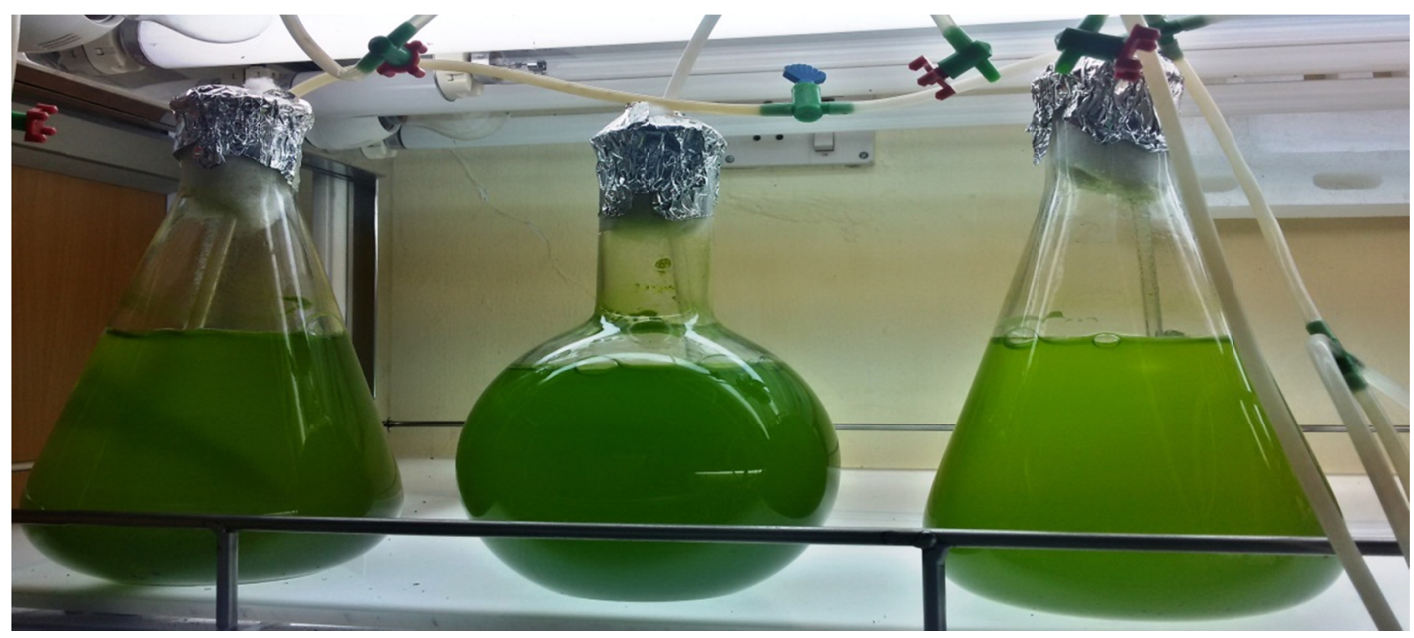

Figure 2. Culture of C. humicola for biomass production of alga in BBM - intensity of colour reveals growth intensity

\subsection{Synthetic Seed Preparation and Test for Long Term Storage Viability}

Synthetic seeds of algae were prepared by using sodium alginate. Sodium alginate (4\%) were prepared in sterilized BBM media and stirred continuously at $60^{\circ} \mathrm{C}$ in a water bath for one hour. One gram of uniculture of algae sample was washed out with sterile water and mixed with prepared sodium alginate slurry in the ratio of 1 volume of cell inoculums: 2 volume of sodium alginate. It was then dropped into $0.2 \mathrm{M}$ calcium chloride solution using a pipette to form calcium alginate beads with algal cells entrapped. The beads were kept for 30 minutes to solidify. They were then washed 3 to 4 times with distilled water. Algal seeds were stored under dark condition in a refrigerator at 4 degree Celsius. At every three month interval, viability of the beads was tested by culture ( 5 beads for $100 \mathrm{~mL}$ culture medium) in BBM to assess their viability.

\subsection{Quantitative Estimation of Carbohydrates}

Carbohydrate content was determined as per the method of Dubois et al. (1956), using glucose as standard; 100 $\mathrm{mg}$ of the lyophilized algal sample was hydrolyzed by keeping it in boiling water bath for three hours with $5 \mathrm{~mL}$ of $2.5 \mathrm{~N} \mathrm{HCl}$ and cooled to room temperature. The total volume was made up to $100 \mathrm{~mL}$ by using double distilled water and centrifuged at $2723 \mathrm{~g}$ for 5 minutes at $4^{\circ} \mathrm{C}$. The supernatant was used for carbohydrate estimation.

\subsection{Quantitative Estimation of Total Proteins}

Total protein content was determined as per the method of Lowry (Lowry, Rosebrough, Lewis, \& Randall, 1951), using bovine serum albumin as standard; $5 \mathrm{mg}$ of freeze dried algal sample was mixed with $5 \mathrm{~mL}$ of $80 \%$ acetone (Rotek vortex mixture: 1331) for 1 minute and centrifuged at $5000 \mathrm{rpm}$ for 5 minutes at $4^{\circ} \mathrm{C}$ and the pellet was homogenized with $0.2 \mathrm{~mL}$ of $24 \% \mathrm{TCA}(\mathrm{w} / \mathrm{v})$ and centrifuged at $7000 \mathrm{rpm}$ for 5 minutes at $4^{0} \mathrm{C}$. The homogenate was incubated at $95^{\circ} \mathrm{C}$ for 15 minute in a water bath and cooled to room temperature. $600 \mu \mathrm{L}$ of ultra pure water was added and centrifuged at $15000 \mathrm{rpm}$ at $4^{\circ} \mathrm{C}$ for 2 minutes. The pellet was collected and re-suspended in 0.5 $\mathrm{mL}$ Lowry D reagent and it was then incubated at $55^{\circ} \mathrm{C}$ for 3 hours. The sample was cooled to room temperature $\left(27^{\circ} \mathrm{C}-30^{\circ} \mathrm{C}\right)$ and centrifuged at $15000 \mathrm{rpm}$ for 20 minutes at $4^{\circ} \mathrm{C}$. The supernatant was collected and used for estimation of total proteins. 


\subsection{Extraction of Algal Oil}

Total lipids were extracted as per the method of Bligh and Dyer (1959) using Soxhlet; $10 \mathrm{gm}$ of freeze dried biomass was taken into a round bottom flask and added $100 \mathrm{~mL}$ of chloroform: methanol $(2: 1 \mathrm{v} / \mathrm{v})$ mixture into the biomass. The biomass was then kept soaked in the organic solvents for $4 \mathrm{hrs}$ under continuous shaking in a rotary shaker at $750 \mathrm{rpm}$; afterwards the mixture was centrifuged at $6000 \mathrm{rpm}$ for 5 minutes at room temperature $\left(27^{\circ} \mathrm{C}-30^{\circ} \mathrm{C}\right)$. Residual biomass was separated from the extract and then the oil along with the solvent was transferred in to a separating funnel. About $40 \mathrm{~mL}$ of distilled water was added to this mixture to separate the oil from the solvent. The oil got separated as an organic phase in bottom layers; this was then collected into a bottle. The separated biomass and the oil were made free of the solvent by using rotary evaporator.

The air dried residual biomass free of the solvent was further subjected to hot method of extraction for collection of the remaining neutral lipids. The biomass was taken in to Soxhlet extractor with $75 \mathrm{~mL}$ of hexane, refluxed under $70^{\circ} \mathrm{C}$ for 2 hours. The extracted oil components were collected and the oil was made-free of the solvent by using rotary evaporator. Finally, the two extracted oil samples were mixed together to get the total oil.

\subsection{Chemical Characterization of Algal Oil}

Chemical characterization of the oil was carried out using the advanced Government of India analytical facility at CARE Kerala, Chalakkudy. Exactly $50 \mathrm{mg}$ of algal oil was saponified with $1 \mathrm{~mL}$ of saturated $\mathrm{KOH}-\mathrm{CH}_{3} \mathrm{OH}$ solution at $50^{\circ} \mathrm{C}$ for 10 minutes and then followed by methanolysis with $5 \% \mathrm{HCl}$ in methanol at $60^{\circ} \mathrm{C}$ for another 10 minutes in screw capped test tubes. The methyl fatty acids were separated by adding $2 \mathrm{~mL}$ of water into it and fatty acid phase was recovered. GC-MS (Agilent make 7890A- 5975C) instrument was used for the fatty acid profiling. $1 \mathrm{~mL}$ of methyl fatty acid sample was injected to the $\mathrm{GC}$ column. Helium was used as carrier gas at flow rate of $54 \mathrm{~mL} / \mathrm{min}$. Chromatographic data was recorded and compared using Agilent data analysis software.

\subsection{Transesterification of Algal Oil and the Production of Biodiesel}

$400 \mathrm{mg}$ of algal oil extracted were taken into a round bottom flask and mixed with $15 \mathrm{~mL}$ of methanolic sulphuric acid containing $2 \%$ sulphuric acid in methanol $(\mathrm{v} / \mathrm{v})$ and refluxed at $60^{\circ} \mathrm{C}$ for 4 hours with continuous shaking. The reaction was monitored by thin layer chromatography (TLC) with the solvent system, Hexane: Ethyl acetate/ hexane: Toluene at the ratio of 9:1. The reaction was continued till the oil spot was disappeared on TLC plate. After the completion of reaction (2-4 hr), the contents were transferred to separating funnel and 25 $\mathrm{mL}$ water was added to it. The aqueous layer was extracted twice with ethyl acetate $(25 \mathrm{~mL}$ each) and pooled the ethyl acetate layer. The extract was dried over anhydrous $\mathrm{Na}_{2} \mathrm{SO}_{4}$ and concentrated under vacuum.

\subsection{FTIR Analysis of Algal biodiesel}

FTIR characterization for 'biodiesel' samples produced was carried out (IS10 FTIR, Thermo Scientific) in transmission mode in $400-4000 \mathrm{~cm}^{-1}$ wave number range.

Fatty acid composition of algal oil

Percentage of oil in algae (\%) was calculated using the formula (Abubakar, Mutie, \& Muhoho, 2012)

$$
=\frac{\text { Weight of oil }(\mathrm{g})}{\text { Dry weight of sample }(\mathrm{g})} \times 100
$$

\section{Results and Discussion}

\subsection{Biomass Productivity of Alga in Vitro Culture Media}

Since BBM is known to enhance maximum production of protein and chlorophyll in green algae (Sankar \& Ramasubramanian, 2012), the same medium was used for the assessment of biomass productivity of $C$. humicola (Table 1) in the current experimentation. Productivity of $73.8 \% \mathrm{mg} / \mathrm{L} /$ day obtained suggests the alga to be a suitable candidate for high yield of biomass and other derivatives, easily amenable to industrial trials. 
Table 1. Biomass productivity, carbohydrates, proteins and lipids contents in the biomass of C. humicola

\begin{tabular}{lc}
\hline Cultural conditions & $\begin{array}{c}\text { Medium } \\
\text { (BBM) }\end{array}$ \\
\hline Quantity of the medium & $1 \mathrm{~L}$ \\
$\mathrm{pH}$ & 7.30 \\
Temp in ${ }^{0} \mathrm{C}$ & $24 \pm 2$ \\
Light intensity (Lux) $^{\text {Duration of days }}$ & 8000 \\
Fresh Weight of inoculums (mg) & 30 \\
Dry weight of inoculums (mg) & 100 \\
Dry weight of biomass after 30 days (mg) & 19.3 \\
Growth of alga mg/L/day & $427.57 \pm 4$ \\
Carbohydrates mg/gm of biomass & $73.8 \%$ \\
Proteins in mg/gm of biomass & $22.4 \%$ \\
Lipids in mg/gm of biomass & $25.5 \%$ \\
\hline
\end{tabular}

\subsection{Experimentation on Long Term Storage and Viability}

In general, encapsulation of micro algae in alginate as 'synthetic-seed-material' (SSM) can be considered a profitable method, to reduce the cost of long-term storage of pure culture or stock maintenance. Synthetic seed material of algae has several other industrial applications such as phycoremediation (Rai \& Mallick, 1992) hydrogen production (Das, 2001) and maintenance of aseptic specimens of algae during culture transportation. In the present experimentation, successful preparation of SSM of C. humicola and its long-term maintenance is achieved (Figure 3). The SSM of C. humicola was stored at $4^{0} \mathrm{C}$ in a usual laboratory refrigerator for about 14 months, and the same was successfully cultured in BBM at every three-month intervals with quite same viability till the $14^{\text {th }}$ month (Figure 4; Table 2). This fact is evidential to viability of the SSM for further duration. Even though, it is well known that alginate encapsulation method of algae maintains ultra structural integrity and normal physiological activities (Corrêa et al., 2009; Dainty, Goulding, Robinson, Simpkins, \& Trevan, 1986) during sufficiently long period of time, this is the first demonstration of retention of green-algae in alginate beads over a year with quite good viability.

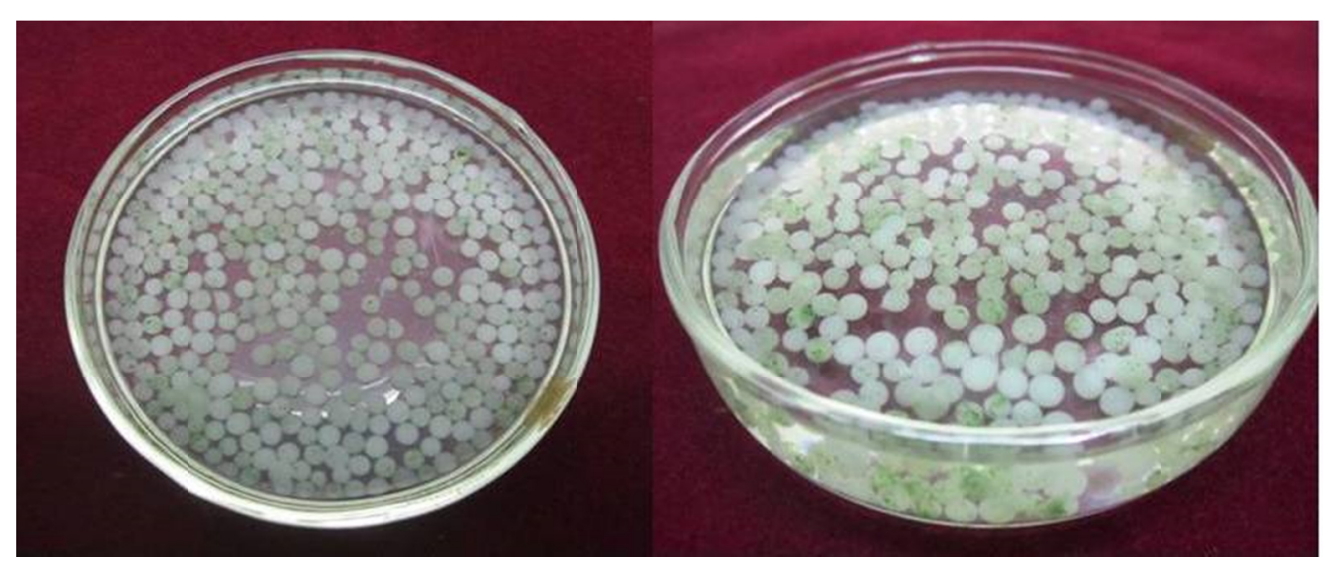

Figure 3. Synthetic seed materials (SSM) of Algal cells after preparation 


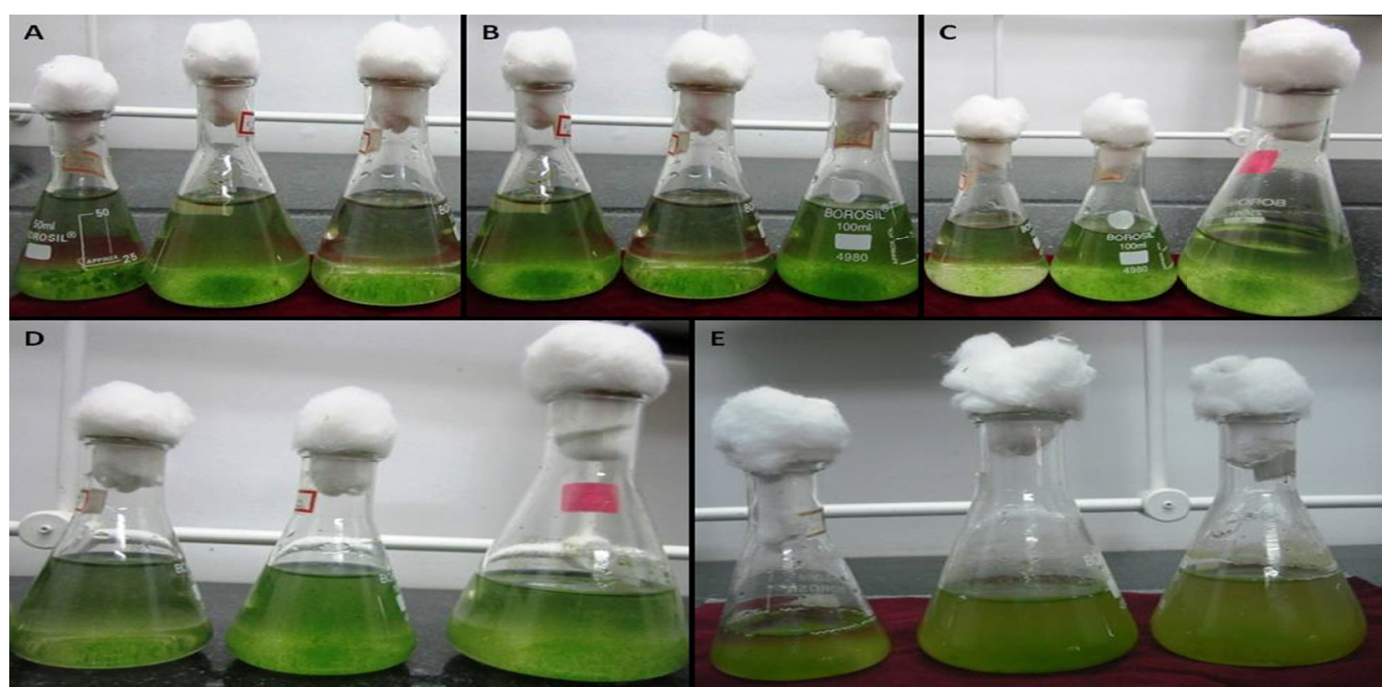

Figure 4. Viability testing by culturing of $C$. humicola in Bold's basal medium: A. after 3 months; B. after 6 months; C. after 9 months; D. after 12 months; E. after 14 months - intensity of the colour reveals equal viability

Table 2. Growth rate of $C$. humicola in terms of number of cells $/ 100 \mathrm{~mL}$ after culture of SSM in BBM at different intervals

\begin{tabular}{|c|c|c|c|c|c|}
\hline $\begin{array}{l}\text { No. of cells in } \\
\text { one seeds/ } \mathrm{mL} \text { of } \\
\text { inoculum }\end{array}$ & $\begin{array}{l}\text { After } 3 \text { month } \\
\text { cells / mL }\end{array}$ & $\begin{array}{l}\text { After } 6 \text { month } \\
\text { cells } / \mathrm{mL}\end{array}$ & $\begin{array}{l}\text { After } 9 \text { month } \\
\text { cells / mL }\end{array}$ & $\begin{array}{l}\text { After } 12 \\
\text { month cells } / \\
\text { mL }\end{array}$ & $\begin{array}{l}\text { After } 14 \\
\text { month cells / } \\
\text { mL }\end{array}$ \\
\hline $1.84 \pm 0.039 \times 10^{6}$ & $13.3 \pm 0.07 \times 10^{7}$ & $13.3 \pm 0.04 \times 10^{7}$ & $13.4 \pm 0.02 \times 10^{7}$ & $13.4 \pm 0.02 \times 10^{7}$ & $13.3 \pm 0.02 \times 10^{7}$ \\
\hline
\end{tabular}

\subsection{Total Proteins, Carbohydrates and Lipids}

Chemical characterization of the biomass of the strain showed $22.4 \%$ carbohydrates, $25.5 \%$ proteins and $13 \%$ of lipids (Table 1). Uma et al. (2015) reported more or less similar protein content for C. humicola cultured in outdoor environments in CFTRI medium enriched with NPK fertilizer; even higher protein content is known for Chlorella sp. cultured in BBM (Sankar \& Ramasubramanian, 2012). But the lipid content observed in the present experimentation using the local strain of $C$. humicola is found to be higher than that of the previous reports. Since protein and lipid content of algae depend not only on the species, but also on diverse environmental conditions (Morris , Smith \& Glover,1981), further standardization for optimum yield of proteins and lipids is essential in the assessment of C. humicola as a protein or lipid-rich algal resource.

\subsection{Transesterification of Oil and FTIR Confirmation of Biodiesel}

Chemical profile of the oil from this alga (Table 3) has shown $70 \%$ monosaturated fatty acids, $17.4 \%$ monounsaturated fatty acids and $12.2 \%$ polyunsaturated fatty acids. Commonly used lipids for biodiesel productions have C16:0 and C18:1fatty acids (Knothe, 2005). Usually algal oil with saturated and poly unsaturated fatty acids containing 14-18 carbon molecules such as C14:0, C16:0, C16:1, C18:1, C18:2, C18:3 are used as the feed-stock for biodiesel productions (Duong, Li , Nowak \& Schenk, 2012; Stansell, Gray \& Sym, 2012). Chemical characterization of the oil extracted from C. humicola obtained in the current investigation revealed that $95.4 \%$ of it is $\mathrm{C} 14-18$ fatty acids.

According to the American Society for Testing and Materials (ASTM) D6751 and European EN 14214 standards, monosaturated fatty acids are given preferences for the production of good quality biodiesels (Knothe, 2005). Moreover, algal oil containing fatty acids such as palmitic, stearic, oleic and Linoleic acids are considered good for biodiesel (Knothe, 2008). Therefore, the oil extracted from C. humicola was subjected to transesterification trials. The IR spectra (Figure 5) peak $1741.72 \mathrm{~cm}^{-1}$ of transesterified algal oil confirmed the formation of biodiesel. Since the quality of the oil remains the same irrespective of the medium used (Mahmah, Chetehouna, \& Mignolet, (2011), this alga may be considered as a good oil resource for biodiesel production; however, further standardization of environmental conditions and media is required to assure the optimum oil yield.

Observation of $12.2 \%$ of the total fatty acids to be of the two important essential fatty acids in this local strain, it 
may be considered a nutraceutically valuable alga. Only a very low concentrations (1.41- 4.04 \%) of Linoleic acid and Linolenic acid (0.19- 0.67\%) is known for Chlorella sp (Hempel, Petrick, \& Behrendt, 2012). Since, Chlorella species are the major group of micro algae used for industrial production of essential fatty acids (Pulz $\&$ Gross 2004), this local strain of C. humicola with significant amount of essential fatty acids may be considered one of the best green algal resources for essential fatty acids.

Table 3. GCMS fatty acid profile of Chlorococcum humicola: *monosaturated fatty acids (70\%), ** monounsaturated fatty acids $(17.4 \%), * * *$ polyunsaturated fatty acids $(12.2 \%)$

\begin{tabular}{|c|c|c|}
\hline Fatty acid profile & Result in $1 \mathrm{ml}(\mathrm{ppm})$ & $\%$ of fatty acids \\
\hline Caproicacid (C6:0)* & 66.04 & 11.2 \\
\hline Undecanoicacid (C11:0)* & 36.51 & 6.2 \\
\hline Lauricacid $(\mathrm{C} 12: 0)^{*}$ & 68.42 & 11.6 \\
\hline Myristicacid (C14:0)* & 66.59 & 11.3 \\
\hline Pentadecanoicacid (C15:0)* & 33.17 & 5.6 \\
\hline Palmiticacid (C16:0)* & 80.29 & 13.6 \\
\hline Palmitoleic acid $(\mathrm{C} 16: 1 \mathrm{cis})^{* *}$ & 34.46 & 5.8 \\
\hline Stearicacid $(\mathrm{C} 18: 0)^{*}$ & 64.86 & 10.9 \\
\hline Oleic acid $(\mathrm{C} 18: 1 \mathrm{cis})^{* *}$ & 68.37 & 11.6 \\
\hline Linoleic acid (C18:2 cis) $)^{* * *}$ & 34.47 & 5.8 \\
\hline Linolenic acid $(\mathrm{C} 18: 3 \mathrm{cis})^{* * *}$ & 37.79 & 6.4 \\
\hline
\end{tabular}

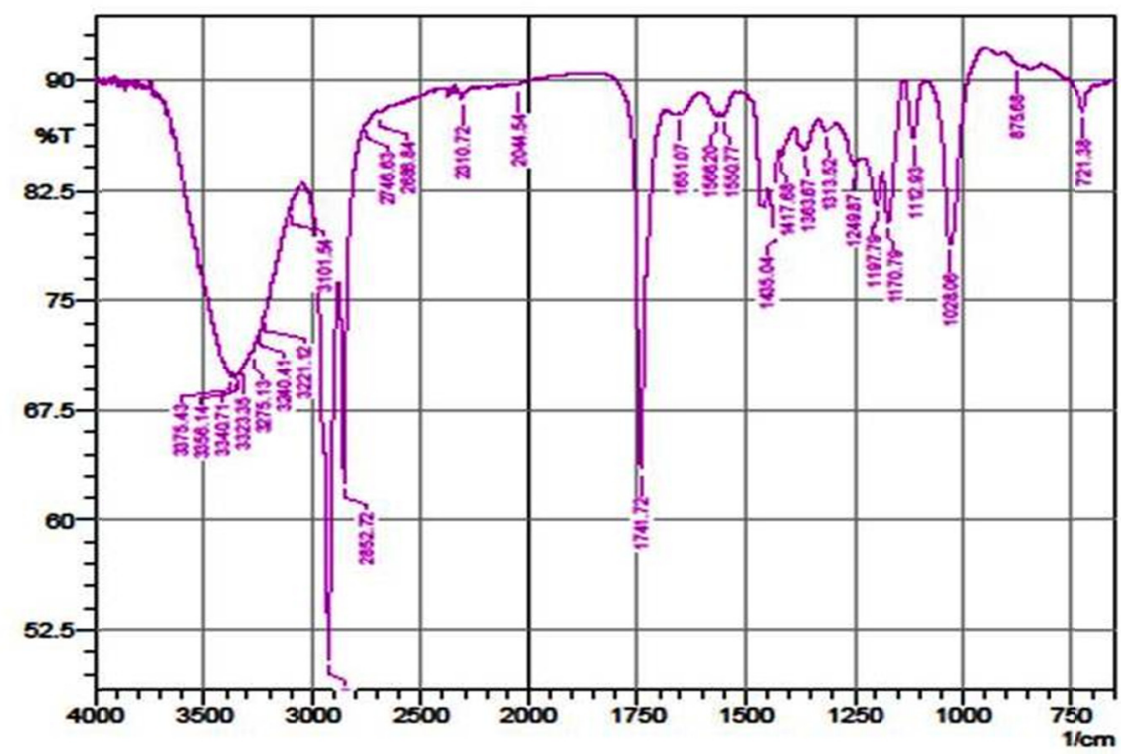

Figure 5. FTIR spectrum of algal biodiesel - peak at $1741.72 \mathrm{~cm}^{-1}$ confirm the formation of biodiesel

\section{Conclusion}

Chemical analysis of the biomass of $C$. humicola has shown that it is rich in carbohydrate, protein and lipids, especially of nutraceutically significant compounds in its oil, which indicate industrial value of this alga. High percentage of monosaturated fatty acids in its oil indicates this local strain of $C$. humicola as a good candidate for biofuel feedstock. Sodium alginate encapsulation method is found quite feasible for maintaining a stock culture of this alga for sufficiently long period of 14 months. Further explorations on lipid production potential of this alga in different media under varied levels of diverse nutrients and heterotrophic conditions are essential for ensuring its industrial applications. 


\section{Acknowledgment}

Authors wish to acknowledge the support received for UV Spectrum analytical facilities at institute for intensive research in basic sciences (IIRBS) and FTIR facility of Department of Biotechnology, Government of India at School of Biosciences, Mahatma Gandhi University.

\section{References}

Abubakar, L. U., Mutie, A. M., \& Muhoho, A. (2012). Characterization of Algae Oil ( Oilgae ) and its Potential As Biofuel in Kenya. Journal of Applied Phytotechnology in Environmental Sanitation, 1(4), 147-153.

Andersen, R. A. (2005). Algal Culturing Techniques (p. 578). UK: Elsevier Academic Press.

Becker, E. W. (1994). Microalgae: Biotechnology and Microbiology (p. 262). Cambridge, NY: Cambridge Univ. Press.

Becker, E. W. (2007). Micro-algae as a source of protein. Biotechnology Advances, 25, 207-210. http://dx.doi.org/10.1016/j.biotechadv.2006.11.002

Benatti, P., Peluso, G., Nicolai, R., \& Calvani, M. (2004). Polyunsaturated fatty acids: biochemical, nutritional and epigenetic properties. Journal of the American College of Nutrition, 23, 281-302. http://dx.doi.org/10.1080/07315724.2004.10719371

Bhagavathy, S., Sumathi, P., \& Jancy Sherene Bell, I. (2011). Green algae Chlorococcum humicola- a new source of bioactive compounds with antimicrobial activity. Asian Pacific Journal of Tropical Biomedicine, 1, S1-S7. http://dx.doi.org/10.1016/S2221-1691(11)60111-1

Bligh, E., \& Dyer, W. (1959). A Rapid Method of Total Lipid Extraction and Purification. Canadian Journal of Biochemistry and Physiology, 37, 911-917. http://dx.doi.org/10.1139/o59-099

Chiu, S., Kao, C., Chen, T., Chang, Y., Kuo, C., \& Lin, C. (2015). Cultivation of microalgal Chlorella for biomass and lipid production using wastewater as nutrient resource. Bioresource Technology, 184, 179-189. http://dx.doi.org/10.1016/j.biortech.2014.11.080

Corrêa, X. R., Tamanaha, M. S., Horita, C. O., Radetski, M. R., Corrêa, R., \& Radetski, C. M. (2009). Natural impacted freshwaters: In situ use of alginate immobilized algae to the assessment of algal response. Ecotoxicology, 18, 464-469. http://dx.doi.org/10.1007/s10646-009-0301-x

Dainty, A. L., Goulding, K. H., Robinson, P. K., Simpkins, I., \& Trevan, M. D. (1986). Stability of alginate-immobilized algal cells. Biotechnology and Bioengineering, 28, 210-216. http://dx.doi.org/10.1002/bit.260280210

Das, D. (2001). Hydrogen production by biological processes: a survey of literature. International Journal of Hydrogen Energy, 26, 13-28. http://dx.doi.org/10.1016/S0360-3199(00)00058-6

Dubois, M., Gilles, K. A., Ton, J. K. H., Rebers, P. A., \& Smith, F. (1956). Colorimetric Method for Determination of Sugars and Related Substances. Analytical Chemistry, 28, 350-356. http://dx.doi.org/10.1021/ac60111a017

Duong, V. T., Li, Y., Nowak, E., \& Schenk, P. M. (2012). Microalgae isolation and selection for prospective biodiesel production. Energies, 5, 1835-1849. http://dx.doi.org/10.3390/en5061835

Faafeng, B. A., Donk, E., \& Källqvist, S. T. (1994). In situ measurement of algal growth potential in aquatic ecosystems by immobilized algae. Journal of Applied Phycology, 6, 301-308. http://dx.doi.org/10.1007/BF02181943

Fleurence, J. (1999). Seaweed proteins.Trends in Food Science \& Technology, 10, 25-28. http://dx.doi.org/10.1016/S0924-2244(99)00015-1

Gao, M. T., Shimamura, T., Ishida, N., \& Takahashi, H. (2012). Investigation of utilization of the algal biomass residue after oil extraction to lower the total production cost of biodiesel. Journal of Bioscience and Bioengineering, 114, 330-333. http://dx.doi.org/10.1016/j.jbiosc.2012.04.002

Gatenby, C. M., Orcutt, D. M., Kreeger, D., Parker, B. C., Jones, V. A., \& Neves, R. J. (2003). Biochemical composition of three algal species proposed as food for captive freshwater mussels. Journal of Applied Phycology, 15, 1-11. http://dx.doi.org/10.1023/A:1022929423011

Gaudin, P., Lebeau, T., \& Robert, J. M. (2006). Microalgal cell immobilization for the long-term storage of the marine diatom Haslea ostrearia. Journal of Applied Phycology, 18, 175-184. http://dx.doi.org/10.1007/s10811-006-9092-0 
Hempel, N., Petrick, I., \& Behrendt, F. (2012). Biomass productivity and productivity of fatty acids and amino acids of microalgae strains as key characteristics of suitability for biodiesel production. Journal of Applied Phycology, 24, 1407-1418. http://dx.doi.org/10.1007/s10811-012-9795-3

Ignarro, L. J., Balestrieri, M. L., \& Napoli, C. (2007). Nutrition, physical activity and cardiovascular disease: an update. Cardiovascular Research, 73, 326-340. http://dx.doi.org/10.1016/j.cardiores.2006.06.030

Johnson, F. X. (2008). Industrial Biotechnology and Biomass Utilisation. Futur Prospect for Industrial Biotechnology, 196.

Knothe, G. (2005). Dependence of biodiesel fuel properties on the structure of fatty acid alkyl esters. Fuel Processing Technology, 86, 1059-1070. http://dx.doi.org/10.1016/j.fuproc.2004.11.002

Knothe, G. (2008). "Designer" biodiesel: Optimizing fatty ester composition to improve fuel properties. Energy and Fuels, 22, 1358-1364. http://dx.doi.org/10.1021/ef700639e

Lowry, O. H., Rosebrough, N. J., Lewis, A. F., \& Randall, R. J. (1951). The folin by oliver. Readings, 193, 265-275. http://dx.doi.org/10.1016/0304-3894(92)87011-4

Mahmah, S. C. B., Chetehouna, K., \& Mignolet, E. (2011). Biodiesel production using Chlorella sorokiniana a green microalga. Revue des Energies Renouvelables, 14, 21-26.

Morais, M. G., \& Costa, J. A. V, (2007). Biofixation of carbon dioxide by Spirulina sp. and Scenedesmus obliquus cultivated in a three-stage serial tubular photobioreactor. Journal of Biotechnology, 129, 439-445. http://dx.doi.org/10.1016/j.jbiotec.2007.01.009

Moreno-Garrido, I. (2008). Microalgae immobilization: Current techniques and uses. Bioresource Technology, 99, 3949-3964. http://dx.doi.org/10.1016/j.biortech.2007.05.040

Morris, I., Smith, A. E., \& Glover, H. E. (1981). Products of photosynthesis in phytoplankton off the Orinoco River and in the Caribbean Sea. Limnology and Oceanography, 26, 1034-1044. http://dx.doi.org/10.4319/lo.1981.26.6.1034

Murugesan, A. G., Maheswari, S., \& Bagirath, G. (2008). Biosorption of cadmium by live and immobilized cells of Spirulina platensis. International Journal of Environmental Research, 2, 307-312.

Olofsson, M., Lamela, T., Nilsson, E., Bergé, J. P., Del Pino, V., Uronen, P., \& Legrand, C. (2012). Seasonal variation of lipids and fatty acids of the microalgae Nannochloropsis oculata grown in outdoor large-scale photobioreactors. Energies, 5, 1577-1592. http://dx.doi.org/10.3390/en5051577

Phillipose, M. T. (1967). Chlorococcales, ICAR, Monograph on Algae (pp. 73-74). New Delhi,

Pulz, O., \& Gross, W. (2004). Valuable products from biotechnology of microalgae. Applied Microbiology and Biotechnology, 65, 635-648. http://dx.doi.org/10.1007/s00253-004-1647-x

Rai, L. C., \& Mallick, N. (1992). Removal and assessment of toxicity of $\mathrm{Cu}$ and Fe to Anabaena doliolum and Chlorella vulgaris using free and immobilized cells. World Journal of Microbioly \& Biotechnology, 8, 110-4. http://dx.doi.org/10.1007/BF01195827

Sankar, M., \& Ramasubramanian, V. (2012). Biomass production of commercial algae Chlorella vulgaris on different culture media. E-Journal of Life Sciences, 1, 56-60.

Scott, A., \& Bryner, M. (2006, December). Alternative fuels: Rolling out next generation technologies. Chemical week (pp. 20-27).

Spolaore, P., Joannis-Cassan, C., Duran, E., \& Isambert, A. (2006). Commercial applications of microalgae. Journal of Bioscience and Bioengineering, 101, 87-96. http://dx.doi.org/10.1263/jbb.101.87

Stansell, G. R., Gray, V. M., \& Sym, S. D. (2012). Microalgal fatty acid composition: Implications for biodiesel quality. Journal of Applied Phycology, 24, 791-801. http://dx.doi.org/10.1007/s10811-011-9696-x

Travieso, L., Benitez, F., Weiland, P., Sánchez, E., Dupeyrón, R., \& Dominguez, A. R. (1996). Experiments on immobilization of microalgae for nutrient removal in wastewater treatments. Bioresource Technology, 55, 181-186. http://dx.doi.org/10.1016/0960-8524(95)00196-4

Uma, R., Sivasubramanian, V., \& S. N. D (2015). C. humicola in fertilizer based outdoor cultivation. Indian Journal of Pharmaceutical Science \& Research, 5, 19-22.

Yamaguchi, K. (1997). Recent advances in microalgal bioscience in Japan, with special reference to utilization of biomass and metabolites: a review. Journal of Applied Phycology, 8, 487-502. 
http://dx.doi.org/10.1007/BF02186327

\section{Copyrights}

Copyright for this article is retained by the author(s), with first publication rights granted to the journal.

This is an open-access article distributed under the terms and conditions of the Creative Commons Attribution license (http://creativecommons.org/licenses/by/3.0/). 